Article

\title{
Social Network Analysis of the Jangwi Urban Regeneration Community
}

\author{
Hwanbae Kim ${ }^{1, * \mathbb{D}}$, Jae-Kyoung Chung ${ }^{2}$ and Myeong-Hun Lee ${ }^{2, *}$ \\ 1 Department of Frontier Architectural and Urban Environment Engineering, Graduate School of Hanyang \\ University, 222 Wangsimni-ro, Seongdong-gu, Seoul 04763, Korea \\ 2 Graduate School of Urban Studies, Hanyang University, 222 Wangsimni-ro, Seongdong-gu, \\ Seoul 04763, Korea \\ * Correspondence: hb1370@hotmail.com (H.K.); mhlee99@hanyang.ac.kr (M.-H.L.); \\ Tel.: +82-10-7236-1370 (H.K.); +82-2-2220-4418 (M.-H.L.)
}

Received: 14 May 2019; Accepted: 1 August 2019; Published: 2 August 2019

check for updates

\begin{abstract}
The administrative turn to urban regeneration in South Korea prompts an examination into the social aspects of sustainability for project areas. This retrospective study used social network analysis (SNA) to compass the 2015-2018 formation of Jangwi urban regeneration community, with average degree, centralization, and efficiency for network level and degree for individual level. The study aimed to identify the network's structural characteristics in terms of relationships and social linkage. Average degree results note a rise in social exchange (2015: 0.609; 2018: 4.060), while the 2018 centralization value $(<0.5)$ and community efficiency indicate how such network communication is dependent on key influencers. Introduced is a visual and quantitative analysis method for community networks that may warrant urgent attention in the field of Korean urban regeneration, as it provides potential strategies for governments and administrations to accomplish sustainable and strategic goals.
\end{abstract}

Keywords: social network analysis; urban regeneration; community; sustainable social development; new deal policy; social relation

\section{Introduction}

\subsection{Study Background and Purpose}

Since the 1980s, projects for reconstruction and redevelopment in South Korea have invested where surplus profits were a guarantee [1]. However, it is not only that such gentrification ousted tenants and dismantled a sense of community [1,2]; the priority in surplus profits also overlooked-if not caused-blighted neighborhoods with insufficient funds and measures to maintain amenities and infrastructure [3]. The reparative shift for urban development came in 2007 when the national government announced its goal "to build a living city," which would later anticipate the "Special Act on the Promotion of and Support for Urban Regeneration" of 2013, for revitalizing the welfare of declining communities [2,4]. The acts soon after precipitated the 2017 Urban Regeneration New Deal Project (도시재생 뉴 딜사업) of the then newly elected Moon administration. Under the New Deal policy, regional governments with various local actors were required to formulate innovative urban regeneration strategies for competitive state subsidy bidding, a grant that would cover $50 \%$ of the project's costs with the remainder to be borne by local governments [2].

The funding is not indefinite, however, as the efforts must aim to strengthen local capacity for eventual financial independence. The term "urban regeneration" refers to such strengthening, including the introduction of new functions and utilization of resources for a city affected by depopulation, 
changes in industrial structure, and indiscriminate expansion. It is an integrated approach that encourages the voluntary participation of citizens for sustainable growth and adds new physical, economic, environmental, and social functions based on partnership [5]. With the emphasis on public-private relationships for organizational structure and fair operation, urban regeneration projects could proceed without being ruled out by interests of involved stakeholders [6]. Of particular interest is the local government's Urban Regeneration Support Center, the costs of which are secured through the grant as well as support from public corporations, businesses, and donations [7]. The Center seeks to foster competencies in managerial skills and values in sustainability-done through seminars and educational programs held by government-funded experts in the field-for residents to autonomously carry on the revitalization process. Additionally, the Center's coordinators mediate communication among the central and local governments and residents, and disseminate relevant information to said parties.

Nevertheless, the nationwide competition for sponsorship under the New Deal policy may have been a decision made too quickly. Local approaches did not account for community participation in the past, such that there is no empirical data or analysis to evaluate the performances of organizations that had to form nonetheless. Though active discussions on ways to support and promote community organizations were expected to occur nationwide, most local governments had yet to learn how to communicate and implement their cooperatives efficiently. Despite cooperative planning as the policy's core principle [8], it is not easy to objectively evaluate or monitor social aspects where a public fund is invested. As in the past, physical development would receive principal focus to assure direct results and justify budget expenditures. Ahn et al. [9] note that, regardless, the annual rate of maintained community organization decreased from $88.2 \%$ in the second year to $48.3 \%$ in the sixth year, while the communities formed were unable to attain the skillsets needed in time (e.g., fiscal management and business model creation). This added difficulty presents that, if financial support were discontinued without a proper plan and relations in place, there would be high risks of severance for existing networks and citizen participation in sustaining the area $[10,11]$.

It would thus be necessary to examine one of the 13 pilot areas for urban regeneration chosen in December 2014. This particular study conducted a social network analysis (SNA) to identify the structural characteristics and influencers of the Jangwi urban regeneration community, a network that gained recognition from the Seoul Metropolitan Government for its exemplary performance [12] in its first stage. An in-depth analysis of Jangwi's progress from beginning to end may offer ways to cultivate interaction among members [13], assess and diagnose the network structure, and provide insightful implications for sustaining areas that would undergo urban regeneration in the future. Below is an outline of the Center's social regeneration program (Table 1).

While the plan presents a continuity for urban regeneration, it also lists the projects held per stage of development. The educational programs in stage 1 include a field trip to Suwon (a model urban regeneration area), urban farming, home repair, rainwater utilization, and basic urban regeneration concepts. The competencies formed will have equipped residents to lead and plan their own projects for stage 2, involving urban agriculture, small-scale house repairs, installation of rainwater facilities, and holding local festivals. Such were thought to encourage deeper involvement and on-the-job training until the development of an autonomous citizen body at the end of stage 3. For Jangwi, the official program of the Seoul Metropolitan Government should have ended in 2018, yet because stage 3 had not yet been completed, it was decided that the urban regeneration project extend for another year through the constant requests of the citizens. In the process, however, uncertainties over the extended support and the employment instability at the end of 2018 led to the withdrawal of a considerable number of coordinators-the key mediators between the city government and the region's residents. As the Center serves as the primary means for integrating and coordinating the projects-some of which were led by residents already [7]—the social network that it, the government, and the citizens have built together may be cut off. 
Table 1. Three stages of the Jangwi social regeneration program [14].

\begin{tabular}{|c|c|}
\hline Stage & Description \\
\hline $\begin{array}{l}\text { 1. Project Preparation } \\
\text { (2015) }\end{array}$ & $\begin{array}{l}\text { - Identify the citizen community } \\
\text { - } \quad \text { Develop a basic citizen education program for the residential and urban environment } \\
\text { invited experts and explore other cases }\end{array}$ \\
\hline $\begin{array}{l}\text { 2. Strengthening Capacity } \\
\text { (2016-2018) }\end{array}$ & $\begin{array}{l}\text { - } \quad \text { Cultivate the identified community } \\
\text { - Train citizens in skills for project leadership and further skills development } \\
\text { - } \quad \text { Organize teams and personnel by project } \\
\text { Hold activities such as operating a regional hub space, improving alleys, and creating } \\
\text { eco-friendly villages }\end{array}$ \\
\hline $\begin{array}{l}\text { 3. Building of the } \\
\text { Implementation System } \\
\text { (2018) }\end{array}$ & $\begin{array}{l}\text { - } \quad \text { Establish a sustainable citizen-led implementation system } \\
\text { - } \quad \text { Organize the Jangwi Urban Regeneration Cooperative } \\
\text { - } \quad \text { Prepare executive groups via said business model }\end{array}$ \\
\hline
\end{tabular}

\subsection{Social Network Analysis and Community Organization}

Previous SNA studies on community organizations held that social networks contribute to living satisfaction, generosity and reciprocity between individuals, and social unity; in turn, they follow that factors such as trust, social capital, and communication enhance or drive communal capacity for collaborative urban planning [11,15-18]. Such studies used the number of neighbors, the number and intensity of the activities of the organization, and the increase in participation of the citizen meetings relative to project costs as indicative SNA measures (Table 2). Though effective, these studies encountered difficulties in data collection, as individual community members found it difficult to objectively recognize an individual's impact and ability given his or her relational position in the network.

Table 2. Prior social network analysis (SNA) studies on communities in urban regeneration.

\begin{tabular}{cll}
\hline Researcher & \multicolumn{1}{c}{ Study Theme } & \multicolumn{1}{c}{ Indicative Measure for SNA } \\
\hline $\begin{array}{c}\text { Lee Y et al. } \\
(2008)[15]\end{array}$ & $\begin{array}{l}\text { A Study on the Capacity Building for } \\
\text { Citizens' Participation in Urban } \\
\text { Regeneration }\end{array}$ & $\begin{array}{l}\text { Number of contacts and meetings between } \\
\text { neighbors, number of visits to friends' homes, } \\
\text { conversation length, etc. }\end{array}$ \\
\hline $\begin{array}{c}\text { Choh } \\
(2010)[16]\end{array}$ & Policy Issues of Social Capital in Seoul & $\begin{array}{l}\text { Number of contacts between neighbors, number of } \\
\text { organizations participated, personal credibility, } \\
\text { public credibility, etc. }\end{array}$ \\
\hline $\begin{array}{c}\text { The Seoul Institute } \\
\text { (2011) [17] }\end{array}$ & $\begin{array}{l}\text { Development and Application of Regional } \\
\text { Comprehensive Diagnostic Indicators for } \\
\text { Sustainable Community Regeneration }\end{array}$ & $\begin{array}{l}\text { Status of low-income vulnerable citizens, tenant } \\
\text { ratio, residence period of citizens, etc. }\end{array}$ \\
$\begin{array}{c}\text { Shin Y } \\
\text { (2012) [11] }\end{array}$ & $\begin{array}{l}\text { The Influence of Community Capacity on } \\
\text { Continuing and Expanding Participation }\end{array}$ & $\begin{array}{l}\text { Number of participant organizations, personal } \\
\text { relationship, personal credibility, public credibility, } \\
\text { strength of organizational cooperation, etc. }\end{array}$ \\
\hline $\begin{array}{c}\text { MOLIT } \\
\text { (2013) [18] }\end{array}$ & $\begin{array}{l}\text { A Study on the Establishment of Basic } \\
\text { Measures for Urban Regeneration in Korea }\end{array}$ & $\begin{array}{l}\text { Increased participation in citizen gatherings related } \\
\text { to the satisfaction of livelihood and the cost of the } \\
\text { project (project/KRW mil.) }\end{array}$ \\
\hline
\end{tabular}

The present study thus attempted an actor-level use of SNA to measure individual influence in addition to a network-level approach similar to the studies mentioned. The stipulation is that an accurate assessment of how an organization is managed and what specific parts actors play in it can come from a birds-eye point of view of the whole network. Actors are any unit of two: e.g., an individual to an organization, to a company, to a patent; the relationship formed between two actors is a link, a dyadic characteristic that exists when both actors maintain mutual connection [19]. 
For Spinks [20], actors can refer to SNA as a strategic viewpoint to take "proactive measures to strengthen network ties," voicing their norms, ideals, and opinions with their effect over others. Similarly, Dale and Newman [21] believe that the lack in both coherent dialogue and an ethos of sustainable development among stakeholders (i.e., the "gridlock") can be mitigated via key individuals who connect different members of the network. In a sense, Dale, Newman, and Spinks place value on direct human relations for community building, such that this study defines "community" as a social network of people with shared values and interests who share information, opinions, trust, and camaraderie among one another. The Jangwi urban regeneration community comprises, in turn, the members of the project, members of the Center, and the local government officers.

Additionally present in a community is social capital, classified as either "bonding" or "bridging," in which bonding social capital is a high-density network internal to a community [22] between actors and links. Meanwhile, "bridging social capital" is characterized by the external connections a network has with other groups and communities [23,24]; actors are grouped according to demographic differences (e.g., age, ethnicity, class; [25]) or based on sources of information, knowledge, and finance from the different groups [26]. Although this study could have proceeded thus by clustering citizens, coordinators, and government officials in a pattern after Woolcock and Narayan [26], or by demographic differences following Portes [25], the method did not appear needed. The Jangwi network could be fully visualized in a network map and was not large enough to substantially cluster 119 respondents into subgroups.

Furthermore, though bonding and bridging can be considered as two separate connection types, Leonard and Onyx [27] argue that they need not be mutually exclusive. At the same time, Crowe asserts that network analysis can distinguish the different degrees of both bridging and bonding capital, as conceptual models for empirically measuring their types are not provided. The different levels of bridging and bonding capital are distinguishable by analyzing the network structure through the actors and links; indeed, how the relationship of the actors and links are defined determine a network's structure [28], which can be mathematically and visually expressed through SNA.

Reference to the network structure in regard of the actors and links may lead to a better evaluation of network practices and decision-making for stakeholders such as identifying which facets need further attention or how the cooperative should continue. Regional development and community establishment, for example, can be assessed and managed in a fundamentally different way: planners can refer to SNA to gradually discuss policy implications by visualizing how the community is organized, noting its characteristics, and classifying them appropriately under regional development, community building, and community interaction [29-32].

\section{Materials and Methods}

\subsection{Subject Area}

In the context of this study, the community organization's shared values and interests were those of the urban regeneration project. The actors were the members, coordinators, and government officials of the Jangwi Urban Regeneration Project; the links were information sharing, opinion sharing, trust, and camaraderie, constitutive of the whole network of community organization. The direct relationships were examined through a survey to build the data. Afterward, the social network analysis was conducted in a differentiated way such that the structural relationship, growth, and personal influence of the community organization were quantitatively assessed and analyzed.

The exact address of the study area is 232-17 Jangwi-dong, Seongbuk-gu, Seoul, South Korea. As the network was already formed from the educational and training programs in 2015, the area appeared to be an ideal place for SNA. The area had 317 residents, 6 coordinators, and 5 public officials included in the Center's list as participants in the urban regeneration projects or events. Of the total 328, responses from 119 participants were gathered (37.5\%): 108 residents, 6 support center coordinators, and 5 public officials of the Seongbuk-gu office. Sixty of the 108 were members of the consultative 
body; 48 of them were residents who participate in the urban regeneration project (Table 3). The consultative body, formed under Article 21 of the "Special Act on the Promotion of and Support for Urban Regeneration," is autonomous in terms of project and financial management, though the Center provides venues for meetings and consultations.

Table 3. Number of survey respondents.

\begin{tabular}{|c|c|c|c|c|c|}
\hline & Resident & & Coordinators & Public Official & Total \\
\hline Participants & $\begin{array}{c}108 \\
\text { Consultative Group Member } \\
60\end{array}$ & $\begin{array}{c}\text { Ordinary } \\
48\end{array}$ & 6 & 5 & 119 \\
\hline
\end{tabular}

\subsection{Selection of Survey Questions}

The survey questions in the present study were derived from prior research related to social relations such as communality capacity and social capital (Table 4). The studies on social capital emphasized the trust between the government and the citizenry, or between neighbors, and found that friendship and exchange between neighbors are the factors that strengthen solidarity and community organizations $[11,33,34]$. The studies highlighting the community's capability to maintain relationships recognize not only the camaraderie, but also the exchange of opinions as factors that improve social problems and the ability to solve conflicts, whereas opinion and information sharing are factors that maintain cooperative relations with the public $[11,15,34]$.

Table 4. Prior studies reviewed to determine survey questions.

\begin{tabular}{cccccccc}
\hline Question & $\begin{array}{c}\text { Lee Y. et al. } \\
\text { (2008) [15] }\end{array}$ & $\begin{array}{c}\text { Choh } \\
\text { (2010) [16] }\end{array}$ & $\begin{array}{c}\text { Ro and Koo } \\
\text { (2012) [33] }\end{array}$ & $\begin{array}{c}\text { Shin } \\
\text { (2012) [11] }\end{array}$ & $\begin{array}{c}\text { Lee Y. } \\
\text { (2014) [34] }\end{array}$ & $\begin{array}{c}\text { CYRAM } \\
\text { (2016) [35] }\end{array}$ & $\begin{array}{c}\text { Adapted/Not } \\
\text { Adopted }\end{array}$ \\
\hline $\begin{array}{c}\text { Information sharing } \\
\text { Cooperative relation } \\
\text { General sharing } \\
\text { Reciprocity }\end{array}$ & $\bullet$ & $\bullet$ & $\bullet$ & $\bullet$ & $\bullet$ & $\bullet$ & Adapted \\
$\begin{array}{c}\text { Opinion sharing } \\
\text { Trust }\end{array}$ & $\bullet$ & $\bullet$ & $\bullet$ & $\bullet$ & $\bullet$ & & \\
$\begin{array}{c}\text { Business relations } \\
\text { 친밀감 }\end{array}$ & $\bullet$ & $\bullet$ & $\bullet$ & $\bullet$ & $\bullet$ & $\bullet$ & $\begin{array}{c}\text { Adapted } \\
\text { Adapted }\end{array}$ \\
\hline
\end{tabular}

${ }^{1}$ As the translation is "closeness," which may be confused with the term used in SNA, this Korean term will be referred to as "camaraderie" instead.

The present study selected survey questions to examine the Jangwi community network according to the relationships ("information sharing," "opinion sharing," "trust," and "camaraderie"), in consideration of community competence and social capital (Table 5; Tables S1 and S2). The four relationships are features that facilitate interaction among members of the community; the criteria and questions were patterned after the work of CYRAM [35], a programming company and SNA software developer, with a research institute that regularly conducts SNA for South Korean governments and businesses.

The questions were presented during face-to-face interviews with members of the Jangwi Urban Regeneration Area, held at the Urban Regeneration Support Center from 2-31 December 2018. The respondents were given a list of all 317 community members; those who relocated outside of the Jangwi community were excluded. The interviewees could point out as many people from the list as they could. The first set of interviews comprised members visiting the center; the second were members who had, or were currently working on, projects; the third set of interviews was for members who were cited frequently by others and were possible influencers. As a type of snowball sampling, the process initially began with the highly active members at that time until there were no more additional actors available to survey. The interviewees were also asked to disclose the longevity of their relationships with the people they refer to examine the characteristics and changes in the acquaintance network. Additionally, the managing director of the support center, other coordinators, and core influencers 
identified via SNA were interviewed to better understand the causes of the SNA results to discuss what had happened at that time, how personal connections were made, and what activity was being done.

Table 5. Survey questions.

\begin{tabular}{cl}
\hline Type of Network & \multicolumn{1}{c}{ Question } \\
\hline Information sharing & $\begin{array}{l}\text { Who has provided you with useful information on the urban } \\
\text { regeneration project? }\end{array}$ \\
Opinion sharing & $\begin{array}{l}\text { Who in your neighborhood do you often talk to about issues in the } \\
\text { urban regeneration project? (e.g., areas in need of improvement, } \\
\text { conflicts, and difficulties) }\end{array}$ \\
Camaraderie & You are going on a long bus trip. Who among the members of your \\
community would you feel comfortable sitting next to?
\end{tabular}

The full surveys are presented in Tables S1 and S2, in Korean and English, respectively.

\subsection{Method of Social Network Analysis}

SNA involves actors and links, in which the nature of the latter constitutes the network. At the network level, average degree, centralization, and efficiency were used while degree was used for the actor level, in line with previous studies [35-39]. There are, however, challenges in capturing changes in social relations over time for SNA that may present a problem to the study [40]. Despite how observations were made at discrete time points, Snijders [41] observed that the resulting dynamics is a result of a continuous time-process. In agreement with Bidart and Lavenu [42] (p. 360), "personal networks have a history. The form and structure they show today result from a construction elaborated over time." Thus, if a connection changed at an initial time, it was assumed in this study that the tie would not change, as SNA can involve static assumptions [43]. In this way, given that the interviewees disclose the year they acquainted with the actors they refer to in the surveys, data prior to 2018 could therefore be retroactively obtained (Table 6; Figure 1).

Table 6. Network data based on the answer to the survey, "the year you first got to know the person."

\begin{tabular}{|c|c|c|c|c|c|c|}
\hline Source & Target & Weight & Year & & Relation & Year \\
\hline $\mathrm{A}$ & B & 1 & 2015 & \multirow{4}{*}{ or } & $A \rightarrow B$ & 2015 \\
\hline A & $\mathrm{C}$ & 1 & 2016 & & $A \rightarrow C$ & 2016 \\
\hline $\mathrm{A}$ & $\mathrm{D}$ & 1 & 2017 & & $\mathrm{~A} \rightarrow \mathrm{D}$ & 2017 \\
\hline A & E & 1 & 2018 & & $\mathrm{~A} \rightarrow \mathrm{E}$ & 2018 \\
\hline
\end{tabular}

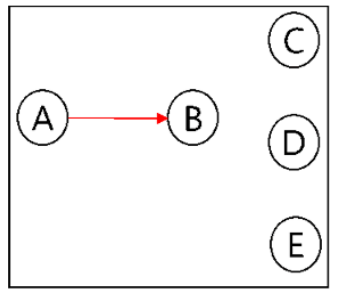

2015

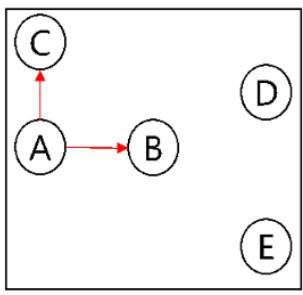

2016

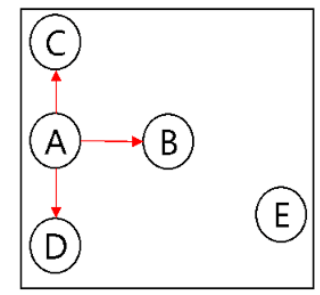

2017

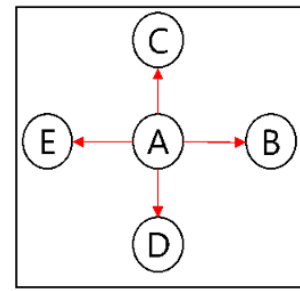

2018

Figure 1. Network map of actors and ties. 
First, the degree analysis of the network's engagement typically has three indicators to determine the degree of activity in the network: average degree, the proportion of isolated members, and whether the network is connected and unbroken [19]; the average degree functioned as the criteria to examine the relationships' quantitative growth. As expressed in the following formula [44]:

$$
\text { average degree }=\frac{L}{N}
$$

$L:$ the sum of links in a network; $N$ : the sum of nodes in a network

the average degree measures how many relationships each member forms in the network on average; for which, the more interrelationships that are formed, the higher the value. The dynamic spread of the network is visualized in the results.

Second, the study looked at centralization and efficiency to analyze the characteristics of the network structure. Centralization is expressed as a ratio between 0 and 1, while its visual (Figure 2) is a "concentration map" that intuitively identifies herding: this can be expressed as in Formula (2) [37]:

$$
\begin{gathered}
C_{D}=\frac{\sum_{i}^{g}\left[C_{D}\left(N^{*}\right)-C_{D}\left(N_{i}\right)\right]}{(g-2)(g-1)} \\
C_{D} \text { : Centralization; } C_{D}^{\left(N^{*}\right)} \text { : highest Degree Centrality; } C_{D}^{\left(N_{i}\right)}: \text { Degree Centrality of node } i ; g: \text { the number of nodes }
\end{gathered}
$$

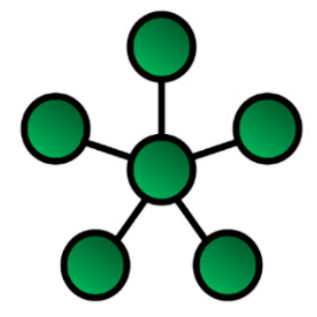

(a) Star network (centralization $=1$ )

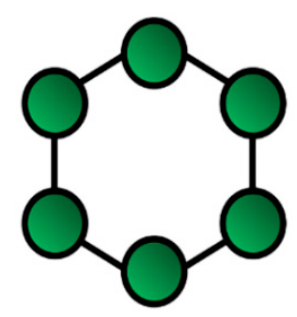

(b) Ring network (centralization $=0$ )

Figure 2. Concentration map for centralization measurement.

Points are placed on the concentric circle. The larger the value of a point, the more centered the point is within the circle. The smaller the value of the point, the farther away it is from the circle center. If centralization is 0.5 or higher, it indicates that the network relies on a small number of citizens, while centralization between 0.3 and 0.4 is a generally observed level [35].

The efficiency of a network structure is measured by average distance from one citizen to another citizen. It can be expressed as in Formula (3) [19].

$$
\begin{gathered}
\text { Average Distance }=\frac{\sum d\left(n_{i}, n_{i}\right)}{g(g-1)} \\
d\left(n_{i}, n_{i}\right): \text { shortest distance between two node; } g: \text { number of nodes }
\end{gathered}
$$

Efficiency, on the other hand, represents whether the network is time-consuming and costly for actors to communicate and agree with each other. To this end, the distance is measured by connecting people with people (Figure 3).

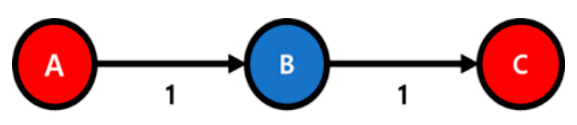

Figure 3. Efficiency (Distance Measurement).

Finally, influencer analysis identifies who or which group of members of the urban regeneration project influence the network structure of the community when forging decisions. It examines whether the initiative of urban regeneration is in place with the citizens. The members who take such initiative 
are interviewed to review their characteristics. The influencer indicator is the number of individuals pointed out by others in the survey, measured by in-degrees. In-degrees refer to the connection in the incoming direction relative to one node. With reference to the average number of connections in the reference network in CYRAM'S report being 5.2 [35], the present study selected people cited by five or more others as an influencer in the survey.

\section{Results}

\subsection{Overview of Survey and Respondents}

The gender of the survey respondents was mainly female (73\%). By age, respondents in their $40 \mathrm{~s}$ to 60 s accounted for most of the survey: $33 \%$ of whom were in their 40 s, $22 \%$ in their 60 s, and $21 \%$ in their 50 s. Fifty percent (50\%) of the respondents were members of the residents' council, while $40 \%$ of the respondents were ordinary citizens. Coordinators accounted for $5 \%$ while civil servants accounted for $4 \%$ of the respondents. By lodging type, $67 \%$ of the respondents were house owners and $33 \%$ of the respondents lived in rented homes. Seventy-six percent $(76 \%)$ of the respondents lived in the area before the first urban regeneration project began in 2015, of which $34 \%$ had lived in the area for more than 20 years (Table 7).

Table 7. Statistics of survey respondents.

\begin{tabular}{|c|c|c|c|c|c|c|}
\hline \multicolumn{3}{|c|}{ Question } & \multirow{3}{*}{$\begin{array}{c}\text { Ratio } \\
27 \% \\
73 \%\end{array}$} & \multirow{3}{*}{$\begin{array}{c}\text { Question } \\
\text { Resident status }\end{array}$} & \multicolumn{2}{|c|}{ Ratio } \\
\hline \multirow{2}{*}{ Gender } & \multirow{2}{*}{\multicolumn{2}{|c|}{$\begin{array}{c}\text { Men } \\
\text { Women }\end{array}$}} & & & Own & $67 \%$ \\
\hline & & & & & Rented & $33 \%$ \\
\hline \multirow{4}{*}{ Composition } & \multirow{2}{*}{ Residents } & Ordinary & $50 \%$ & \multirow{3}{*}{ Housing type } & Condominium & $16 \%$ \\
\hline & & Members & $40 \%$ & & Single house & $46 \%$ \\
\hline & \multicolumn{2}{|c|}{ Coordinators } & $5 \%$ & & Apartment & $37 \%$ \\
\hline & \multicolumn{2}{|c|}{ Public official } & $4 \%$ & & 1 yr less & $7 \%$ \\
\hline \multirow{5}{*}{ Age } & \multicolumn{2}{|c|}{$20 \mathrm{~s}$} & $7 \%$ & & $1-5$ yrs & $18 \%$ \\
\hline & \multicolumn{2}{|c|}{$30 \mathrm{~s}$} & $18 \%$ & Period of residence & $5-10$ yrs & $19 \%$ \\
\hline & \multicolumn{2}{|c|}{$40 \mathrm{~s}$} & $33 \%$ & & $10-15$ yrs & $14 \%$ \\
\hline & \multicolumn{2}{|c|}{$50 \mathrm{~s}$} & $21 \%$ & & $15-20 \mathrm{yrs}$ & $9 \%$ \\
\hline & \multicolumn{2}{|c|}{$60 \mathrm{~s}$} & $22 \%$ & & Over 20 yrs & $34 \%$ \\
\hline
\end{tabular}

\subsection{Level of Network}

\subsubsection{Average Degree}

The study examined the average degree and its changes over time to determine the extent of network activity. It was centered on the types of network present (opinion and information sharing, camaraderie, and trust) among the citizens of Jangwi Urban Regeneration Area. While $76 \%$ of the members participating in the Jangwi Urban Regeneration Area had lived there for five years or longer, the average degree was only 0.331 before 2015 . The succeeding years observed an average growth rate of $92 \%: 84 \%$ in $2015,151 \%$ in $2016,104 \%$ in 2017 , and $30 \%$ in 2018; of which the 0.609 average degree value at the beginning of the project in 2015 rose to 4.060 come 2018 (Table 8).

Table 8. Average degree.

\begin{tabular}{cccccc}
\hline Type & Before the Project & $\mathbf{2 0 1 5}$ & $\mathbf{2 0 1 6}$ & $\mathbf{2 0 1 7}$ & $\mathbf{2 0 1 8}$ \\
\hline Whole & 0.331 & 0.609 & 1.526 & 3.120 & 4.060 \\
Information sharing & 0.225 & 0.392 & 0.961 & 1.853 & 2.353 \\
Opinion sharing & 0.296 & 0.469 & 0.988 & 2.272 & 2.877 \\
Camaraderie & 0.253 & 0.446 & 0.940 & 1.928 & 2.590 \\
Trust & 0.291 & 0.481 & 0.987 & 1.975 & 2.544 \\
\hline
\end{tabular}


According to the annual growth, the network appeared to have formed in 2015 and activated about twice every year until 2017, as long-term residents who were once strangers to each other came to interact more frequently (Figure 4). The network growth appears concurrent with the efforts of the support center outlined earlier (Table 1), and especially so in regard to the various skill-building activities, such as urban regeneration education programs and public contests held in April 6, 2016 (Table 9).

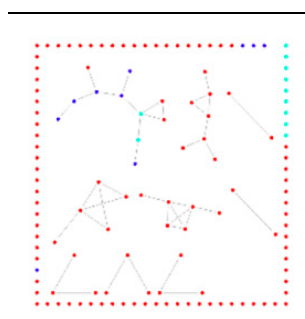

(a) Before Project

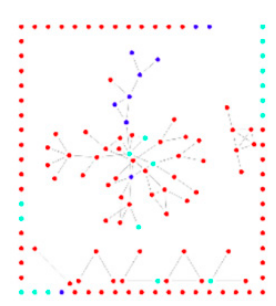

(b) 2015

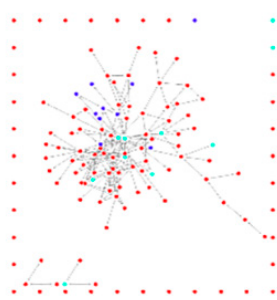

(c) 2016

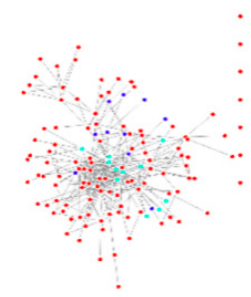

(d) 2017

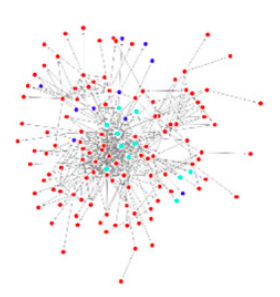

(e) 2018

Figure 4. Network map (before the project and 2015-2018). In the network map, citizens were marked in red, coordinators in green and officials in blue. Members located on the outside are the isolated members. The corroborated data was obtained from the survey (see Table 6 and Figure 1).

Table 9. Social regeneration activity.

\begin{tabular}{|c|c|c|c|c|}
\hline Particular & 2015 & 2016 & 2017 & 2018 \\
\hline $\begin{array}{l}\text { Government-led } \\
\text { activities }\end{array}$ & $\begin{array}{l}\text { Conference, } 1 \\
\text { activation pla }\end{array}$ & earing, survey, & & \\
\hline \multirow{3}{*}{$\begin{array}{l}\text { Support center-led } \\
\text { activities }\end{array}$} & $\begin{array}{l}\text { Community } \\
\text { education of }\end{array}$ & $\begin{array}{l}\text { field trips, basic } \\
\text { egeneration }\end{array}$ & & \\
\hline & & \multicolumn{3}{|c|}{$\begin{array}{l}\text { Operation of hubs, advanced training by project, organizing public contests, } \\
\text { and supporting for planning }\end{array}$} \\
\hline & & & & $\begin{array}{l}\text { Supporting the formation } \\
\text { of cooperatives }\end{array}$ \\
\hline \multirow{2}{*}{$\begin{array}{l}\text { Citizen-led } \\
\text { activities }\end{array}$} & \multicolumn{4}{|c|}{$\begin{array}{l}\text { Participating in advanced training and skill-building training, supporting } \\
\text { and operating public contests for the project }\end{array}$} \\
\hline & & & & $\begin{array}{l}\text { Formation of urban } \\
\text { regeneration cooperatives }\end{array}$ \\
\hline
\end{tabular}

\subsubsection{Centralization}

Centralization is an indicator of the degree typically dependent on a small number of citizens which others move toward. If centralization is 0.5 or above, it is seen to be dependent on a small number of people, but centralization of Jangwi's overall network in 2015 was 0.0204 and 0.2362 in 2018. Jangwi was thus found not to be dependent on a few citizens compared to typical centralization (Table 10).

Table 10. Network centralization.

\begin{tabular}{cccccc}
\hline & Before the Project & $\mathbf{2 0 1 5}$ & $\mathbf{2 0 1 6}$ & $\mathbf{2 0 1 7}$ & $\mathbf{2 0 1 8}$ \\
\hline Whole & 0.0204 & 0.0412 & 0.1410 & 0.2204 & 0.2362 \\
Information sharing & 0.0177 & 0.0461 & 0.1204 & 0.1715 & 0.1765 \\
Opinion sharing & 0.0342 & 0.0573 & 0.1267 & 0.1738 & 0.1661 \\
Camaraderie & 0.0216 & 0.0439 & 0.0501 & 0.0996 & 0.1285 \\
Trust & 0.0352 & 0.0457 & 0.0911 & 0.1432 & 0.1617 \\
\hline
\end{tabular}

However, the centralization map of the network in Figure 5a shows that citizens, coordinators, and civil servants were evenly positioned in the center at the early stage of the project in 2015, indicating 
equal influence. In 2018, on the other hand, the positions of the civil servants and citizens were more or less on the outside, while the concentration of influence on the coordinators positioned them at center (Figure 5b). In the centralization map, citizens were marked in red, coordinators in green, and officials in blue.

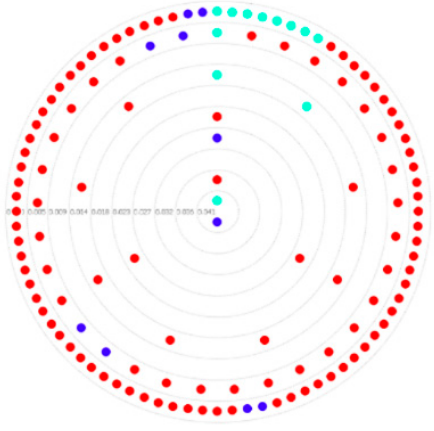

(a) 2015

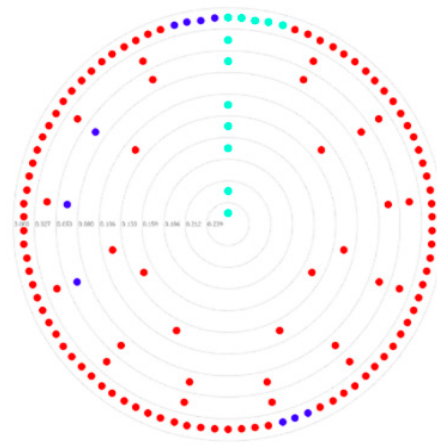

(b) 2018

Figure 5. Centralization map for years 2015 (a) and 2018 (b).

The purpose of the urban regeneration support center is to bridge communications between citizens and the administration until the citizens can sustain the area independently. As the SNA demonstrates, the coordinators have been at the center of the opinion-sharing network and trust network, acting as such between the citizens and civil servants. If these networks do not have coordinators, five groups and six isolated nodes would appear in "Information Sharing," three groups and four isolated nodes would appear in "Opinion Sharing," four groups and eight isolated nodes appear in "Trust," and a relatively stable relationship would only appear in "Camaraderie." If the role of the urban renewal support center is reduced and existing coordinators are removed, there is a risk that the connection between the citizen and the public will disappear as shown in the network map in Figure 4, which would retract the community's progress.

Should the coordinators suddenly disappear from the network, there would be a need to establish a variety of alternative paths, such as members or channels of communication, which can act as a bridge between citizen and administration. In the network map, citizens were marked in red, coordinators in green, and officials in blue (Figure 6).

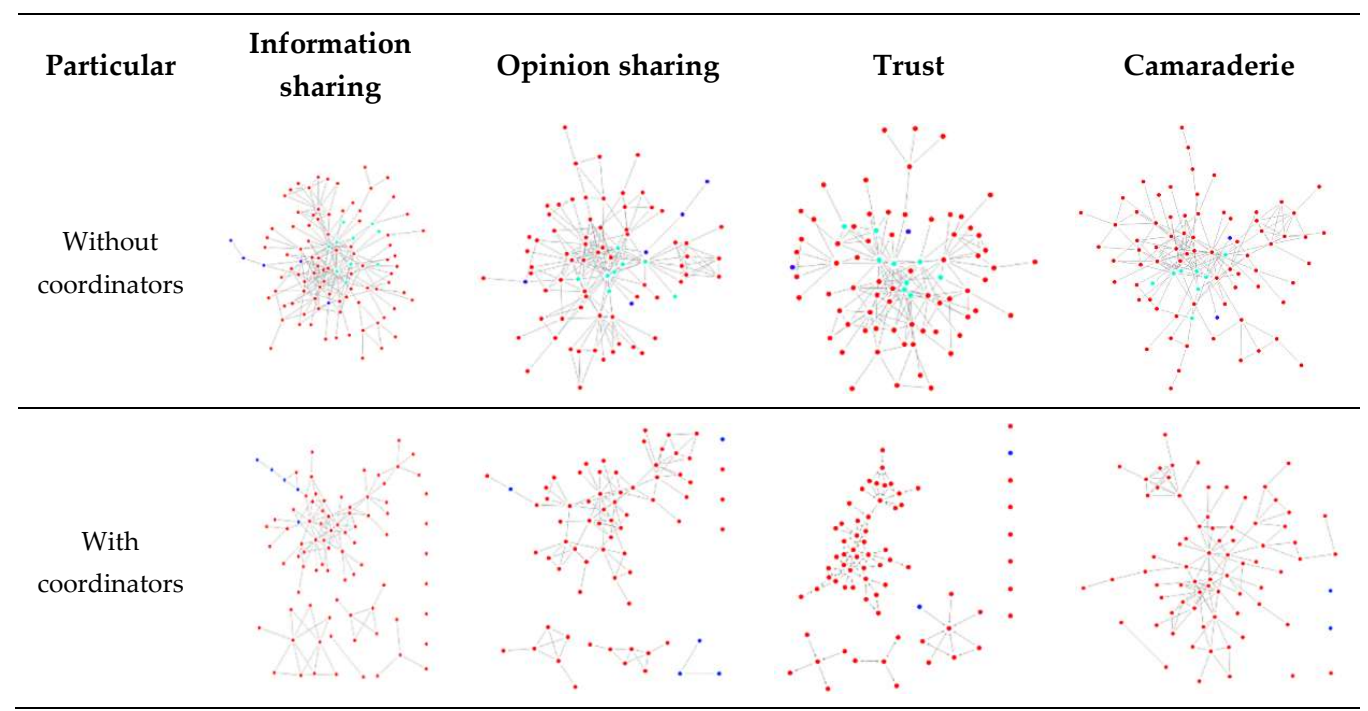

Figure 6. Comparison of the network in 2018. 


\subsubsection{Efficiency}

Average distance and efficiency share an inverse relationship: higher the indicators of average distance, the lower the efficiency, and vice versa. The total number of network members rose by 31 people from 2015-2016 (33\%) and again from 2016-2017 (25\%). However, the average distance gradually increased by 2017 for the entire network, thereby reducing efficiency. The efficiency increased again in 2018 as the average distance decreased (see Table 11). In particular, the efficiency of the "Opinion Sharing" and "Trust" networks increased with the lowered average distance between 2017 and 2018, which saw an increase in the number of members. The results of the citizen interview show that the two coordinators who joined the project in 2018 are located between the existing networks and have contributed to lowering the network's average distance while lowering the overall network's largest distance (diameter) by one notch.

Table 11. Number of members connected and the average distance (dia) in network.

\begin{tabular}{|c|c|c|c|c|c|c|c|c|c|c|}
\hline & \multicolumn{2}{|c|}{ Before the Project } & \multicolumn{2}{|c|}{2015} & \multicolumn{2}{|c|}{2016} & \multicolumn{2}{|c|}{2017} & \multicolumn{2}{|c|}{2018} \\
\hline & Population & $\begin{array}{l}\text { Average } \\
\text { Distance }\end{array}$ & Population & $\begin{array}{l}\text { Average } \\
\text { Distance }\end{array}$ & Population & $\begin{array}{l}\text { Average } \\
\text { Distance }\end{array}$ & Population & $\begin{array}{l}\text { Average } \\
\text { Distance }\end{array}$ & Population & $\begin{array}{l}\text { Average } \\
\text { Distance }\end{array}$ \\
\hline $\begin{array}{l}\text { Information } \\
\text { sharing }\end{array}$ & 30 & 1.143 & 40 & 1.633 & 62 & 2.943 & 90 & 3.041 & 102 & 3.745 \\
\hline $\begin{array}{l}\text { Opinion } \\
\text { sharing }\end{array}$ & 34 & 1.172 & 37 & 1.576 & 54 & 3.200 & 75 & 3.510 & 81 & 3.467 \\
\hline
\end{tabular}

\subsection{Influencers}

Members cited by five or more others were deemed as influencers. Such members fell into one or more of the following criteria: (1) was found in the information sharing network, (2) spread information regarding the project to a large number of people, (3) attended to local problems or difficulties from a large number of members according to the opinion sharing, (4) is perceived as amicable by a large number of citizens (camaraderie), and (5) is trusted by a large number of members.

As the actor level of the SNA, the number of influencers increased from two in 2015 to 28 in 2018 with only one civil servant found to be an influencer. Among the coordinators stationed at the support center, one in 2015, three in 2016, and five in 2017 were found to be influencers. As for citizen-influencers, the number increased sharply from 8 in 2016 to 18 in 2017 as various programs such as public contests and open urban regeneration education programs began in 2016 (Table 12). It is believed that these citizens enhanced the members' will to participate in various public projects and programs.

Table 12. Result of influencer analysis.

\begin{tabular}{ccccccccccccccccc}
\hline Year & \multicolumn{1}{c}{$\mathbf{2 0 1 5}$} & \multicolumn{1}{c}{$\mathbf{2 0 1 6}$} & \multicolumn{4}{c}{$\mathbf{2 0 1 7}$} & \multicolumn{5}{c}{$\mathbf{2 0 1 8}$} \\
\hline Particular $^{\mathbf{1}}$ & $\mathbf{a}$ & $\mathbf{b}$ & $\mathbf{c}$ & $\mathbf{d}$ & $\mathbf{a}$ & $\mathbf{b}$ & $\mathbf{c}$ & $\mathbf{d}$ & $\mathbf{a}$ & $\mathbf{b}$ & $\mathbf{c}$ & $\mathbf{d}$ & $\mathbf{a}$ & $\mathbf{b}$ & $\mathbf{c}$ & $\mathbf{d}$ \\
\hline Information sharing & 1 & 0 & 0 & 1 & 6 & 2 & 3 & 1 & 16 & 4 & 11 & 1 & 19 & 5 & 13 & 1 \\
Opinion sharing & 1 & 1 & 0 & 0 & 3 & 1 & 2 & 0 & 14 & 3 & 11 & 0 & 16 & 4 & 12 & 0 \\
Camaraderie & 0 & 0 & 0 & 0 & 1 & 0 & 1 & 0 & 10 & 2 & 8 & 0 & 16 & 5 & 11 & 0 \\
Trust & 0 & 0 & 0 & 0 & 3 & 1 & 2 & 0 & 13 & 3 & 10 & 0 & 15 & 5 & 10 & 0 \\
Total & 2 & 1 & 0 & 1 & 12 & 3 & 8 & 1 & 24 & 5 & 18 & 1 & 28 & 5 & 22 & $1^{2}$ \\
\hline
\end{tabular}

${ }^{1} \mathrm{a}=$ Total; $\mathrm{b}=$ Coordinator; $\mathrm{c}=$ Citizen; $\mathrm{d}=$ Civil Servant ${ }^{2}$ Duplicated members appearing simultaneously in other networks are excluded from totals.

The citizen-influencers were either executive members of the citizen consultative body or members who actively participated in the body's regular meetings. Most of them were women, married, and house owners. Among the influencers, $40 \%$ had resided in the area for more than 20 years, followed by $23 \%$ who resided for more than five, but less than 10, years. From the characteristics 
of citizen-influencers, it was surmised that they were the ones who spent the most time in the area, are relatively free with their time to form opinions or activities, and lead lives of financial stability. Financial stability was indicated through house ownership, given its difficulty in Seoul.

\section{Discussion}

The study used SNA to provide empirical data for an otherwise theoretical understanding of "community," based on that of the Jangwi community where an urban regeneration project had occurred. The structural features of the community and its influencers leading the urban regeneration project have been visually expressed, quantified, and verified. Although not all community members could participate in the survey because of limited time and resources, the findings remain able to depict the process of Jangwi's network formation. This is better explained in terms of social resource theory. Brass [45] argued that relationships individuals keep are a source of power; a rooted view that actors' positions in social networks are determinants of opportunities and constraints $[46,47]$. The stance that the links constitute the network structure hold the inverse implication, that the actors' links, particularly that of influencers, would appear to reflect-if not greatly contribute to-the formation of the network as a whole.

First, the relationship grew quantitatively in 2018 compared to 2015 in the degree of engagement; the frequent meetings appear to have opened more opportunities to share information and opinions. Not only were there quantitative increases, but positive changes in connectivity were also observed as the number of isolated members decreased while previously disconnected groups became linked together. Interpreted and in line with the observations of CYRAM [35], information and opinions appeared to be frequently shared among members in a constant flow of communication.

Second, the Jangwi social network is not dependent on a few (centralization $<0.5$ ) compared to the typical network. A closer look at the concentrated members, however, show that they were centralized around the coordinators in 2018, proving that the imminent closure of support organizations or the government's suspension of support could threaten the connectivity of the network. There is a risk that the community's network, which has long been built with policy funding, would revert to its state before 2018. As iterated by Ahn et al. [9], discontinuous participation and detached relations would occur from poor coordination between residents and the administration upon project completion, or if support is stopped altogether $[9,10]$. To prepare for withdrawn coordinators because of suspended funding or policy changes and to maintain sustainable public-private partnerships, various alternative routes need to be established in advance, such as new communication channels as well as the promotion of competent members, with whom the administration and government can interact.

Third, the number of members of the network had risen steadily from 2015 to 2018. In 2016 and 2017, the figure rose by a significant $33 \%$, though the average distance increased and lowered the efficiency. In 2018, however, efficiency improved despite another increase in members as two coordinators who started in 2018 were positioned between existing networks, contributing to the lowered average distance of the network. Lee [34] cites that, in an exceptional example of community building, coordinators would have been active since the beginning, forming agreements among various entities and coordinating relationships among stakeholders. The study confirmed that the participation of high-performing coordinators who contribute to better communication and trust could improve the efficiency of the entire network. The finding also supports the claim that SNA can better perceive this to employ a strategic positioning of members in the network. Local governments require a stable and sufficient pool of coordinators in such projects [48]; fostering competency among them is crucial to maintain the network and provide information to residents involved.

Fourth, the total number of influencers increased from two in 2015 to 28 in 2018, with a sharp increase, in particular, to the number of citizen-influencers ( 0 in 2015 to 22 in 2018). More than half were citizens elected for official leadership roles, yet they were not influencers to begin with. Most are homemakers or seniors that could participate in the activities as they are relatively free in the daytime (when most activities and projects were conducted), lead a stable life, and spend much time 
in the area. In the interviews from residents who are now influencers, we found that their urban regeneration efforts were recognized by the local community. We also found that they felt "a sense of social achievement" in the course of conducting contests related to the regeneration project (hosted by Sungbuk-gu and managed by residents) and in receiving skills training-important factors for continuous engagement $[11,15,49]$.

\section{Conclusions}

As the present urban regeneration policy in South Korea lacks empirical backing with its execution, with most local governments unable to efficiently communicate and implement their cooperatives, the present study used social network analysis to identify the quantitative and structural characteristics of community organization, visualized in network maps to offer a systemic view on the position or influence of individuals within the given network. It also examined the changes made to the social network of a community organization, the risk of the network under a change of environment, such as the withdrawal of funds or coordinators and the capacity of influential members to present policy implications.

However, with the present analysis of the members of the urban regeneration area currently underway in Jangwi, there are limitations in that all areas cannot be generalized through the results and implications obtained from this case. This is especially the case with the limited responses from the surveys, the findings of which do no more than represent Jangwi's active participants in the urban regeneration project, which discusses the formation of its respective network. Nevertheless, future studies are suggested to collect more network data from different areas, whether or not they failed or succeeded, to properly apprehend the successes and shortcomings of the current policy or other similar urban regeneration projects. Furthermore, as this study presents a retrospective formation of Jangwi's network, updated studies may instead consider conducting their network investigations and data accumulation in advance. Additionally, criteria for comparative analysis are needed to determine the size of various indicators that describe the characteristics of the network; practical criteria for judgment rather than statistical verification would fit the purpose better. Currently, there are not many examples of a network that could serve as a proper local benchmark. It is expected that if data accumulates through a continuous survey in the same environment, it will enable continuous monitoring and evaluation of urban regeneration by determining the degree of engagement and structural changes when combined with substantial features such as on-site surveys and member satisfaction.

Supplementary Materials: The following are available online at http://www.mdpi.com/2071-1050/11/15/4185/s1.

Author Contributions: Conceptualization, H.K. and J.-K.C.; methodology, H.K.; software, H.K.; validation, H.K. and J.-K.C.; formal analysis H.K.; investigation, H.K.; resources, H.K.; data curation, H.K.; writing-original draft preparation, H.K. and J.-K.C.; writing-review and editing, H.K. and J.-K.C.; visualization, H.K.; supervision, H.K. and M.-H.L.; project administration, H.K. and M.-H.L.; funding acquisition, H.K. and M.-H.L.

Funding: This research received no external funding.

Acknowledgments: The authors received help from Elo Dinglasan, editor of Journal Lab by Lexcode, for use in the English language and developmental editing.

Conflicts of Interest: The authors declare no conflict of interest.

\section{References}

1. Shin, H.B. Property-based redevelopment and gentrification: The case of Seoul, South Korea. Geoforum 2009, 40, 906-917. [CrossRef]

2. Seo, B.K.; Joo, Y.M. Innovation or episodes? Multi-scalar analysis of governance change in urban regeneration policy in South Korea. Cities 2019, 92, 27-35. [CrossRef]

3. Korea Research Institute for Human Settlements (KRIHS). Necessity of Urban Regeneration and Policy Measures; KRIHS Policy Brief No. 416; KRIHS: Anyang, Korea, 2013; Available online: http://eng.krihs.re.kr/whatsnew/ briefView.do?pageIndex=25\&searchCondition=\&searchKeyword=\&eb_idx=1577 (accessed on 20 June 2019). 
4. Kim, H.J.; Kim, R.H. How can the state fund for urban regeneration be improved. J. Korean Urban Manag. Assoc. 2016, 29, 63-90.

5. Roberts, P.W.; Sykes, H. (Eds.) Urban Regeneration: A Handbook; SAGE Publications Ltd.: London, UK, 2008.

6. Kim, B.J.; Lee, W.G. A study on actual condition analysis of cultural industries quarter for urban regeneration. J. Korean Int. Soc. Community Dev. 2009, 34, 33-62.

7. Kim, T.S.; Byun, S.K. Study on Urban Regeneration Support Center; Korea Housing Institute: Seoul, Korea, 2017.

8. Maclver, R.M. Community: A Sociological Study, Being an Attempt to Set Out Native \& Fundamental Laws, 4th ed.; Frank Cass and Co., Ltd.: Abingdon, UK, 2006.

9. Ahn, H.C.; Koo, A.Y.; Cho, Y.J. Study on the Performance Evaluation and Policy Issues of the Community Project in Seoul; Policy Report; The Seoul Institute: Seoul, Korea, 2019; Available online: https://www.si.re.kr/node/60854 (accessed on 20 June 2019).

10. Rado, S.; Baek, S.H.; Noh, T.M. A study on the projects of making a region through the arts. Res. Rep. 2008, pp. 1-168. Available online: http://www.riss.kr/link?id=A103003901 (accessed on 2 May 2019).

11. Shin, Y. An Influence of Community Capacity on Continuous Participation and Expansion toward Community Building. Ph.D. Thesis, Urban Design Faculty, Hanyang University, Seoul, Korea, 2012.

12. Seoul Metropolitan Government. 2025 Urban Regeneration Strategy; Seoul Metropolitan Government: Seoul, Korea, 2018. Available online: https://seoulsolution.kr/sites/default/files/2025\%20\%EC $\% 84 \% 9 \mathrm{C} \% \mathrm{EC} \% 9 \mathrm{~A} \%$

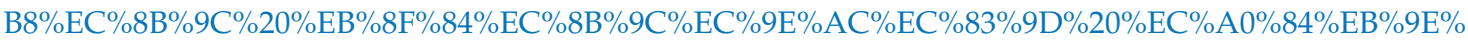
B5\%EA\%B3\%84\%ED\%9A\%8D.pdf (accessed on 5 April 2019).

13. Dempwolf, C.S.; Lyles, L.W. The uses of social network analysis in planning. J. Plan. Lit. 2012, $27,3-21$. [CrossRef]

14. Seoul Metropolitan Government. Urban Regeneration Revitalization Plan in Jangwi-Dong; Seoul Metropolitan Government: Seoul, Korea, 2017; pp. 182-184. Available online: https://uri.seoul.go.kr/surc/archive/ policyView.do?tab_se=POLICYTAB005\&bbs_master_seq=POLICY\&bbs_seq=2768 (accessed on 20 June 2019).

15. Lee, Y.; Byun, P.S.; Ryu, S.H. Capacity Building for Community Development in Korea; Korea Research Institute for Human Settlements: Sejong, Korea, 2008; Available online: http: //library.krihs.re.kr/upload/publication/s_report/http\%3A\%2F\%2Flibrary.krihs.re.kr\%2Fdl_image\% 2FIMG\%2F01\%2F000000003673\%2FSERVICE\%2F000000003673_01.PDF (accessed on 3 May 2019).

16. Choh, K.J. Social Capital of Seoul Metropolitan Area: Current Status and Policy, Policy Report of the Seoul Institute; The Seoul Institute: Seoul, Korea, 2010; Available online: http://www.dbpia.co.kr/journal/articleDetail? nodeId=NODE02001172\&language=ko_KR (accessed on 20 June 2019).

17. The Seoul Institute. A Study on the Community Health Check Indicators for Sustainable Community Regeneration in Seoul; The Seoul Institute: Seoul, Korea, 2011; Available online: https://www.si.re.kr/taxonomy/term/16760 (accessed on 20 June 2019).

18. The Ministry of Land, Infrastructure and Transport. A Study on the Establishment of Basic Policies for Urban Regeneration in Korea. 2013. Available online: https://elaw.klri.re.kr/eng_mobile/viewer.do?hseq=48163\& type $=$ sogan $\&$ key $=4$ (accessed on 20 June 2019).

19. Wasserman, S.; Faust, K. Social Network Analysis: Methods and Applications; Cambridge University Press: Cambridge, UK, 1994; Volume 8.

20. Spinks, M. Understanding and actioning BRE environmental assessment method: A socio-technical approach. Local Environ. 2015, 20, 131-148. [CrossRef]

21. Dale, A.; Newman, L. Social capital: A necessary and sufficient condition for sustainable community development. Community Dev. J. 2010, 45, 5-21. [CrossRef]

22. Taylor, M. Community Issues and Social Networks. In Social Networks and Social Exclusion; Phillipson, C., Allan, G., Morgan, D., Eds.; Ashgate: Burlington, Vermont, 2004; pp. 205-218.

23. Crowe, J.A. In search of a happy medium: How the structure of interorganizational networks influence community economic development strategies. Soc. Netw. 2007, 29, 469-488. [CrossRef]

24. Granovetter, M. Economic action and social structure: The problem of embeddedness. Am. J. Sociol. 1986, 91, 481-510. [CrossRef]

25. Portes, A. Social capital: Its origins and applications in modern sociology. Annu. Rev. Sociol. 1998, $24,1-24$. [CrossRef] 
26. Woolcock, M.; Narayan, D. Social capital: Implications for development theory, research, and policy. World Bank Res. Obs. 2000, 15, 225-249. [CrossRef]

27. Leonard, R.; Onyx, J. Networking through loose and strong ties: An Australian qualitative study. Voluntas 2003, 14, 189-203. [CrossRef]

28. Kim, Y. Social network analysis. J. Korean Reg. Dev. Assoc. 2012, 24, 115-130.

29. Wellman, B. Computer networks as social networks. Science 2001, 293, 4. [CrossRef] [PubMed]

30. Wellman, B. The Persistence and Transformation of Community: From Neighbourhood Groups to Social Networks. Report to the Law Commission of Canada. 2001. Available online: http://groups.chass. utoronto.ca/ netlab/wp-content/uploads/2012/05/The-Persistence-and-Transformation-of-Community-FromNeighbourhood-Groups-to-Social-Networks.pdf (accessed on 20 June 2019).

31. Mandarano, L.A. Social network analysis of social capital in collaborative planning. Soc. Nat. Resour. 2009, 22, 245-260. [CrossRef]

32. Hajer, M.; Zonneveld, W. Spatial planning in the network society-rethinking the principles of planning in the Netherlands. Eur. Plan. Stud. 2000, 8, 337-355. [CrossRef]

33. Ro, J.; Koo, J. The analysis of an impact of resident activities on social capital in residential environment improving projects. J. Korean Reg. Dev. Assoc. 2012, 24, 115-130.

34. Lee, Y. Features and issues of an urban community by analysing residents' awareness and attitude. J. Korean Assoc. Reg. Geogr. 2014, 20, 269-281.

35. CYRAM. Study of Residents-Relationship Network of Residents' Centers in Seoul; Community Support Center of Seoul: Seoul, Korea, 2016.

36. Harary, F. Graph Theory; Addison-Wesley: New York, NY, USA, 1969.

37. Freeman, L.C. Centrality in social networks: I. Conceptual clarification. Soc. Netw. 1979, 1, $215-239$. [CrossRef]

38. Borgatti, S.P.; Everett, M.G. Models of core/periphery structures. Soc. Netw. 1999, 21, 375-395. [CrossRef]

39. Burt, R.S. Range. In Applied Network Analysis: A Methodological Introduction; Burt, R.S., Minor, M.J., Eds.; Sage Publications: Beverly Hills, CA, USA, 1983; pp. 176-194.

40. Ryan, L.; D'Angelo, A. Changing times: Migrants' social network analysis and the challenges of longitudinal research. Soc. Netw. 2018, 53, 148-158. [CrossRef]

41. Snijders, T. Models for longitudinal network data. In Models and Methods in Social Network Analysis; Carrington, P.J., Scott, J., Wasserman, S., Eds.; Cambridge University Press: New York, NY, USA, 2005; pp. 215-247.

42. Bidart, C.; Lavenu, D. Evolutions of personal networks and life events. Soc. Netw. 2005, 27, 359-376. [CrossRef]

43. Borgatti, S.P.; Brass, D.J.; Daniel, S. Halgin Social network research: Confusions, criticisms, and controversies. Res. Sociol. Organ. 2014, 40,1-29.

44. Barabási, A.-L. Network Science Graph Theory; Northeastern University: Boston, MA, USA, 2016; pp. 8-10. Available online: http://barabasi.com/f/625.pdf (accessed on 5 June 2019).

45. Brass, D. Power in Organizations: A Social Network Perspective. In Research in Politics and Society; Moore, G., White, J.A., Eds.; JAI Press: Greenwich, UK, 1992; pp. 295-323.

46. Wellman, B. Structural Analysis: From Metaphor to Theory and Substance. In Social Structures: A Network Approach; Wellman, B., Berkowitz, S.D., Eds.; Cambridge University Press: New York, NY, USA, 1988; pp. 19-61.

47. Stephen, P. Network Measures of Social Capital. Connections 1998, 21, 27-36.

48. Lee, Y.H.; Baek, H.S.; Lee, S.S.; Im, J.M.; Lee, S.J.; Choi, J.S. A Study on the Implementation of Urban Regeneration Support Organization: Focused on the Urban Regeneration Coordinator Promotion Plan, Seoul; Korea Land \& Housing Corporation (LH): Jinju-si, Korea, 2014; Available online: http://hi.lh.or.kr/common/include/file_ download.asp?category=memberdata\&idx=333 (accessed on 20 June 2019).

49. Sung, S.A. Impact Analysis of the Residents Participation Activities in Urban Regeneration Projects. Ph.D. Thesis, Chungbuk National University, Cheongju, Korea, 2015.

(C) 2019 by the authors. Licensee MDPI, Basel, Switzerland. This article is an open access article distributed under the terms and conditions of the Creative Commons Attribution (CC BY) license (http://creativecommons.org/licenses/by/4.0/). 